\title{
SELFBEOORDELING AS 'N VOORSPELLER VAN WAARGENOME GESIMULEERDE BESTUURSVERMOË, SOOS GEMEET IN 'N TAKSEERSENTRUM
}

\author{
N DE BEER \\ LJ VAN VUUREN
}

Departement Menslike Hulpbrombestutir

Randse Afrikaanse Universiteit

\begin{abstract}
Self assessment as a predictor of perceived simulated managerial ability as measured by an assessment centre. The purpose of this study was to establish how accurately a person could assess his own managerial ability. With this in mind, a self-assessment questionnaire was developed. The questionnaire was completed by the participants both before and after participation in an assessment centre. It measured, per managerial dimension, the judgment of the participant that his managerial ability complies with that of a senior departmental manager in the organisation. The before-centre self-assessment scores correlate meaningfully with the after-centre self assessment scores. The selfassessment scores are, however, a poor predictor of the observed simulated managerial ability.
\end{abstract}

\section{OPSOMMING}

Die doel met hierdie studie was om te bepaal in watter mate ' $n$ persoon sy bestuursvermoe korrek kan beoordeel. Met die oog hierop is ' $n$ selfbeoordelingsvraelys ontwerp, wat voor sowel as direk na afloop van deelname aan ' $n$ takseersentrum deur die deelnemers voltooi is. Die vraelys het, per bestuursdimensie, die mate waarin ' $n$ deelnemer van mening is dat sy bestuursvermoè voldoen aan dié van ' $n$ senior afdelingsbestuurder in die organisasie, gemeet. Die voor-sentrum selfbeoordelingtellings en die na-sentrum selfbeoordeling-tellings korreleer betekenisvol. Die voorsentrum selfbeoordelingtellings is egter ' $n$ swak voorspeller van die waargenome gesimuleerde bestuursvermoë.

\begin{abstract}
Die gebruik van selfbeoordelings en ander tipe beoordelings is belangrike elemente in ' $n$ veskeidenheid van menslike hulpbronbestuurstelsels. Dit sluit loopbaanbestuur, keuring, prestasiebestuur, opvolgbeplanning, bestuursopleiding en bestuursontwikkeling in. ' $n$ Beoordelingsinstrument wat al heelwat aandag as ' $n$ doeltreffende meganisme vir die sogenaamde wetenskaplike keuring van bestuurders en die identifisering van bestuurspotensiaal getrek het, is die bestuurstakseer- of beoordelingsentrum (Munchus \& McArthur, 1991, p. 5; Pietersen, 1990, p. 24). In hierdie studie word die verband tussen selfbeoordeling en waargenome bestuursvermoë, soos dit tydens 'n takseersentrum gemeet word, ondersoek. Die takseersentrum - en selfbeoordelingnavorsingsdomein word vervolgens ondersoek, waarna die empiriese komponent van die studie gerapporteer en bespreek word.
\end{abstract}

\section{Takseersentrums}

Die begrip takseersentrum verwys nie na 'n plek nie, maar na 'n metode, tegniek of proses van beoordeling om bestuursvermoë of bestuurspotensiaal te bepaal (Iles, 1992, p. 79). Die fundamentele kenmerke van die takseersentrum is volgens Thornton en Byham (1982) en die "Task force on assessment centre guidelines" ${ }^{\prime \prime}(1989)$ as volg: die gebruik van simulasies en werksvoorbeelde, meervoudige beoordelingstegnieke, opgeleide beoordelaars in die waarneming en verslaglewering van gedrag, waarnemings deur meervoudige beoordelaars en waameming wat van evaluasie geskei is.

Die ontstaan van die takseersentrum kan teruggevoet word na die Tweede Wêreldoorlog waar die tegniek gebruik is vir die identifisering van offisierspotensiaal (Britz, 1984, p. 120; Dulewicz, 1991, p. 32-34). Grootskaalse toepassing het gedurende die 1960 's in die VSA posgevat nadat die nut daarvan deur die American-Telephone and Telegraph (AT\&T) uitgewys is (Bray, Campbell \& Grant, 1974). Takseersentrums se gewildheid word beklemtoon deur die feit dat meer as 2000 organisasies in die VSA teen die middel van die 1980's hierdie tegniek gebruik het (Boehm, 1982; Woodruffe, 1990, p. 5). Die outeurs wil gragg hul opregte dank uitspreek teenoor Prof. Johiann Schepers vir sy
hulp met die statistiese ontleding. Versoeke vir afdrukke moet gerig word aan LT van hulp met die statistiese ontleding. Versoeke vir afanukke moet gerig word aan LI van
Vuuren, Program in Bednjfsielkunde, Departement Menslike Hulpbronbesturu, RAU. Vuuren, Program in Bednjfsielkunde,
Posbus 524, Auckland Park, 2006.
Volgens ' $n$ opname in die Verenigde Koninkryk het meer as ' $n$ derde van maatskappye, met meer as 1000 werknemers in diens, in 1988 van takseersentrum-tegnologie gebruik gemaak (Mabey, 1989).

In Suid-Afrika is takseersentrums reeds sedert 1974 in gebruik (Du Plooy, 1984, p. 12) en speel dit 'n belangrike rol binne die bedryfsielkunde en menslike hulpbronbestuuromgewing (Kriek, 1991, p. 34). Riglyne en etiese oorwegings vir die bedryf van sentrums in Suid-Afrika is in 1991 deur die Takseersentrum Studiegroep van die Instituut vir Personeelbestuur opgestel (Spangenberg, 1991). Gepubliseerde Suid-Afrikaanse navorsing oor takseersentrums is beperk tot studies aangaande geldigheid (cf. Britz, 1984; Spangenberg, Esterhuyse, Visser \& Briedenhann, 1989), kulturele billikheid (cf. Kriek \& Thornton, 1989; Kriek, Hurst \& Charoux, 1994), voorspellingswaarde (cf. Pietersen, 1990; Pietersen 1992), bruikbaarheid (cf. Kriek, 1991) en die gebruik van die Sestien Persoonlikheidsfaktorvraelys (16PF) as hulpmiddel by die takseersentrum (cf. Augustyn \& Van Wyk, 1988).

Takseersentrumtegnologie is een van die primère ontwikkelingsareas in die menslike hulpbron vakgebied gedurende die laaste 30 jaar. Dit het ook navorsingsprojekte met oorwegend positiewe resultate gegenereer (Charoux, 1991, p. 28), en die literatuur met betrekking tot meting vanaf die $1960^{\prime}$ s oorheers (Britz, 1984, p. 117). Die gebruik, koste-effektiwiteit, algemene evaluering en geldigheid van die takseersentrum is in die 1970's en 80 's deeglik nagevors en gedokumenteer (Augustyn \& Van Wyk, 1988, p. 25; Sackett \& Ryan, 1985). Hoewel Dulewicz (1991, p. 50) met die ontleding van 50 takseersentrum valideringstudies getoon het dat die takseersentrum oorwegend 'n baie goeie voorspeller van prestasie is, lewer valideringstudies teenstellende resultate.

Die bedryf van ' $n$ takseersentrum is egter besonder kostearbeidsintensief (Appelbaum, Kay \& Shapiro, 1989, p. 59; Augustyn \& Van Wyk, 1988, p. 25; MacDonald, 1988, p. 50). Die koste implikasie is een van die primêre redes waarom sommige organisasies nie van die tegnologie gebruik maak nie. Die resultate van ' $n$ opname deur Keel, Cochran, Arnett en Arnold (1989, p. 98) waaraan 139 van die "Fortune 500" maatskappye deelgeneem het, toon dat slegs $22 \%$ van dié 
organisasies takseersentrumtegnologie gebruik. Ses en dertig persent van die organisasies wat nie die tegnologie gebruik nie, voer koste en tyd aan as die rede waarom hulle nie daarvan gebruik maak nie. Dit blyk ook dat die takseersentrum meestal vir keuringsdoeleindes gebruik word. In dieselfde studie (Keel et al., 1989) het $50 \%$ van die respondente aangetoon dat die primêre gebruik van die sentrum vir interne keuring-vir-bevordering doeleindes is; $23 \%$ het aangetoon dat die primêre gebruik vir loopbaanontwikkeling is en $16 \%$ het aangedui dat hulle die sentrum hoofsaaklik gebruik vir eksterne keuring (keuring vir indiensneming).

In 'n poging om 'n groter opbrengs of voordeel uit die koste van takseersentrums te verkry, het sommige organisasies begin fokus op die ontwikkelingsaktiwiteite wat uit die sentrum voortspruit (cf MacDonald, 1988, p. 50). Rodger en Mabey (1987) stel voor dat dié tipe sentrum (na aanleiding van hul werk in dié verband by British Telecom), 'n ontwikkelingsentrum genoem kan word. Tydens só 'n sentrum is die klem nie soseer op die totale beoordeling nie, maar meer gerig op die ontwikkelingsbehoeftes soos dit geïdentifiseer word tydens die sentrum (Blanksby \& Iles, 1990). Hierdie metode is reeds met welslae deur verskeie organisasies gebruik, onder andere London Regional Transport (kyk Rayner \& Goodge, 1988).

Griffiths en Allen (1987, p. 19) postuleer dat huidige besigheidsbehoeftes baie verskil van dié wat aanleiding gegee het tot die ontwerp van die oorspronklike sentrum. Die hedendaagse toepassing van takseersentrums verg dat beide die organisasie en die individu se behoeftes bevredig word. Terwyl beoordelings steeds vir keuringsdoeleindes vereis word, vereis snelveranderende markte en mededinging vir bestuurstalent dat maatskappye belê in bestuursontwikkeling (Griffiths \& Allen, 1987). Die gebruik van ontwikkelingsentrums dra dus 'n verskillende boodskap aan afgevaardigdes oor as die tradisionele sentrum. By die tradisionele sentrum is die fokus hoofsaaklik op die beoordeling van bestuurspotensiaal en vermoë, terwyl die klem tydens 'n ontwikkelingsentrum op die ontwikkeling van bestuurspotensiaal is. Tydens die ontwikkelingsentrum is die boodskap dat die deelnemer sy bestuursvermoë by die sentrum laat manifesteer en dat daarna sáám beoordelings gemaak word en bespreek word hoe die persoon sy bestuursvermoë verder kan ontwikkel. Die verantwoordelikheid vir beoordeling het dus verskuif vanaf kundige beoordelaars na die deelnemer self in samewerking met 'n beoordelaar. Woodruffe (1990, p. ??) stel dat dit in sommige gevalle dalk nie nodig is om beoordelaars aan te stel nie. Deelnemers kan hulself beoordeel en daardeur die insig bekom wat nodig is om hulle ontwikkeling te beplan. Hierdie stelling van Woodruffe is gebaseer op die aanname dat mense hulself die beste ken. Volgens Dukes (1988, p. 9) moet daar egter rekening gehou word met die feit dat 'n persoon se eie gedrag moontlik nie vir homself op dieselfde wyse waarneembaar is as wat dit vir ander mense is nie.

\section{Selfbeoordeling}

Met die begrip selfbeoordeling word bedoel 'n persoon se eie evaluering van sy eie vermoëns, kennis, vaardighede en ander persoonlike eienskappe (Levine, 1980, p. 262). Ofskoon selfbeoordeling oor die algemeen as ' $n$ belangrike bron van inligting in 'n verskeidenheid van basiese en toegepaste navorsingskontekste kan dien, is daar tot dusver min navorsingstudies oor selfbeoordeling van bestuurspotensiaal onderneem (Shore, Shore \& Thornton, 1992, p. 43). Heelwat van die literatuur waarna in hierdie artikel verwys word, is studies wat in die 1960's en 1970's onderneem is. Sedert die 1980 's is relatief min studies oor selfbeoordeling onderneem. Min studies ten opsigte van die waarde van selfbeoordeling tydens takseersentrums kon opgespoor word. Volgens Heneman (1980, p. 298) is dit verrassend dat takseersentrumnavorsing tot dusver die aspek van selfbeoordeling uitgelaat het. Hy beweer dat dit die ideale proses vir die formulering en toetsing van spesifieke hipoteses rakende selfbeoordeling is.

Hoewel die gebruik van selfbeoordeling nie gunstig deur sommiges beskou word nie (cf. Thornton, 1968), impliseer ander studies weer dat die selfbeoordeling van vaardighede, kennis en vermoë, waardevolle inligting oplewer (cf. Levine, Flory \& Ash, 1977; Meyer, 1977). In 'n meer resente studie postuleer Brown $(1990$, p. 149) dat individue aktiewe inligtingsoekers is wat daarna strewe om akkurate selfkennis op te doen. In teenstelling hiermee vind Strube, Lott, LeXuân-Hy, Oxenberg en Deichman (1986) dat individue primêr gelei word deur ' $n$ begeerte om ' $n$ positiewe beeld ten opsigte van hulself in stand te hou en te bevorder, en dat hulle daarna streef om 'n positiewe siening van hulself te verdedig (cf. Trope, 1980). Volgens Taylor en Brown (1988) glo die meerderheid van individue dat hulle die vermoë het om te presteer en dat hulle verwag om sukses in prestasieverwante aktiwiteite te behaal. Hoewel studies dus steeds teenstellende resultate lewer, kan aanvaar word dat die grootste beperking van selfbeoordeling is dat individue geneig is om 'n positiewe siening van hulself te huldig (cf. Bradley, 1978; Snyder, Stephan \& Rosenfield, 1976).

Daarbenewens veroorsaak die kompleksiteit van die selfbeoordelingsproses dat dié selfbeoordelingtegniek nie altyd bruikbaar is nie (Levine, 1980, p. 260). Volgens Bandura se teorie (soos aangehaal deur Levine) is daar drie prosesse betrokke in die regulering van gedrag by die self, naamlik: die self-waarnemingproses, die beoordelingproses en die selfevalueringreaksie. Volgens dié teorie kan enige een van dié drie prosesse aanleiding gee tot onakkurate selfbeoordeling.

In die selfbeoordelings-navorsingsdomein is daar ' $n$ aantal hooftemas waarvan die belangrikste die geldigheid van selfbeoordeling is (Furnham \& Stringfield, 1994). (Volgens Guilford, 1973, verwys die begrip "geldigheid" daarna of 'n meetinstrument meet wat dit veronderstel is om te meet.) Daar is aktiewe navorsingsaandag geskenk aan die vooroordele en geldigheid van selfbeoordeling van selfbeoordeling van werksprestasie (Borman, 1974; Thornton, 1980). Mabe en West (1982) hersien ' $n$ aantal geldigheidstudies vind dat daar gemiddeld ' $n$ lae korrelasie tussen die self- en ander beoordelings is. In sy opsomming van selfbeoordelingstudies kom Thornton (1980, p. 268) tot die gevolgtrekking dat individue en ander persone se perspektief oor hul werk verskil. In teenstelling hiermee rapporteer Williams en Seiler in 1973 'n gemiddelde korrelasie van 0,6 tussen die selfbeoordelingresultate en toesighouerbeoordelingsresultate (Borman, 1974). Pym en Auld (1965), waarna verwys word in Borman (1974), se bevindinge oor drie studies lewer 'n gemiddelde korrelasie van 0,56 tussen die selfbeoordelingresultate en toesighouerbeoordelingsresultate. Hieruit kan afgelei word dat daar 'n redelike mate van ooreenstemming tussen die twee beoordelingwyses voorkom.

'n Tweede hooftema wat eers meer onlangs na vore gekom het, is die invloed van kulturele verskille in beoordelings. Navorsingsresultate toon dat kulturele faktore selfbeoordeling van werksprestasie beïnvloed (Furnham \& Stringfield, 1993). Fahr, Dobbins en Cheng (1991) se studie lewer getuienis van 'n "nederige" vooroordeel, waar werknemers in Taiwan hulle eie werksprestasie minder gunstig aangeslaan het as hulle toesighouers.

In 'n oorsig van tersake literatuur is slegs een toepaslike SuidAfrikaanse studie oor selfbeoordeling gevind. Smit (1986) bevind dat ' $n$ selfbeoordelingvraelys, wat voor, sowel as direk na afloop van ' $n$ takseersentrum afgeneem word, daartoe bydra dat ' $n$ persoon 'n groter mate van insig in sy be-stuursvermoë kan verkry.

Ten spyte van die invloed wat self-sydigheid op die selfbeoordelingresultate kan hê, het die selfbeoordelingsproses heelwat toepassingsmoontlikhede. Die studies van Carroll en Schneier (1982), sowel as dié van Cummings en Schwab (1973), soos aangehaal deur Harris en Schaubroeck (1988), impliseer dat selfbeoordeling gebruik kan word om persoonlike ontwikkeling te bevorder, kommunikasie tussen toesighouers en ondergeskiktes te verbeter en meningsverskille op te klaar. Levine et al. (1977) stel voor dat selfbeoordeling kan dien as kriterium waarteen ander beoordelingsprosedures gevalideer kan word, aangesien die gebruik van selfbeoorde- 
lings van vaardighede en kennis dalk geldige inligting vir keuring kan bied. Volgens Levine et al. kan selfbeoordeling ook moontlik as plaasvervanger dien vir sekere prestasietoetse wat duur is om te administreer.

Teen die voorafgaande teoretiese agtergrond van takseersentrum- en selfbeoordeling-navorsing gesien, is die doel met hierdie studie tweeledig, naamlik om eerstens te bepaal of selfbeoordeling van bestuursvermoë ' $n$ voorspeller van waargenome gesimuleerde bestuursvermoë is. ' $n$ Tweede doelstelling van die ondersoek is om te toets of deelname aan ' $n$ takseersentrum ' $\mathrm{n}$ invloed op die persoon se selfbeoordeling van sy bestuursvermoë gehad het, dit wil sê of daar'n verband tussen selfbeoordeling voor deelname aan 'n takseersentrum en selfbeoordeling na deelname aan ' $n$ takseersentrum is.

In die lig van die doelstelling van die studie, is die volgende postulaat en hipotese geformuleer:

\section{Postulaat 1}

Selfbeoordeling van bestuurspotensiaal, voor deelname aan 'n takseersentrum, kan gebruik word om waargenome gesimuleerde bestuursvermoë, soos beoordeel in ' $n$ takseersentrum, te voorspel.

\section{Hipotese 1}

$\mathrm{H}_{1}$ * Daar is ' $n$ statisties beduidende verband tussen selfbeoordeling van bestuurspotensiaal voor deelname aan ' $n$ takseersentrum, en selfbeoordeling van bestuurspotensiaal na deelname aan 'n takseersentrum.

\section{METODE}

Die takseersentrum van ' $n$ groot vervoermaatskappy in SuidAfrika is vir die doeleindes van hierdie studie gebruik. Die tegniek word reeds sedert 1976 in die organisasie gebruik. Dié takseersentrum is ook een van die weinige sentrums in SuidAfrika wat reeds gevalideer is (cf. Britz, 1984). Die resultate van die sentrum word vir indiensneming-, bevordering-en ontwikkelingsdoeleindes gebruik.

Die teikenbestuursvlak vir die sentrum is seniorbestuur. Hierdie bestuursvlak is wat die inhoudelike betref, vergelykbaar met wat tradisioneel in die meeste kleiner organisasies as topbestuur beskryf word (Britz, 1984, p. 203). Die teikenposvlak, uitgedruk in terme van ' $n$ erkende posevalueringstelsel, is ' $n$ Paterson posvlak D3 tot D4 (kyk Auld (1990) vir 'n bespreking van die Paterson posevalueringstelsel,) Die posvlakke van die deelnemers wissel van 'n D1 tot D3 Paterson-posvlak.

Die reeks oefeninge en simulasies in die takseersentum, wat drie dae duur om af te handel, bestaan uit twee groepoefeninge en vier individuele oefeninge. Die groepoefeninge, waarvan een ' $n$ besigheidspel is, is leierloos. Die individuele oefeninge bestaan uit 'n posmandjie, ' $n$ gestruktureerde agtergrondsonderhoud, ' $n$ feitestelling en besluitnemingsoefening, en 'n raadgewingsonderhoud.

Drie administrateurs en ses waarnemers word per takseersentrum aangestel en 12 deelnemers word per sentrum geakkommodeer. Die waarnemers neem twee deelnemers per oefening waar en word geroteet na elke oefening. Die deelnemer se gedrag word dus deur meer as een waarnemer beoordeel, wat meebring dat die beoordelings onafhanklik van mekaar is. Die feit dat verskillende waarnemers die deelnemer se gedrag beoordeel verhoog die interbeoordelaar-betroubaarheid. Dieselfde drie administrateurs woon in die meeste gevalle al die sentrums by. Daardeur word die konsekwente toepassing van die metingsnorm bewerkstellig.

Die 13 bestuursdimensies wat tydens die sentrum beoordeel word, is selfontwikkeling, inisiatief, deursettingsvermoë, analitiese vermoë, beplanning en organisering, oordeelsvermoë, buigsaamheid, mensbenutting, beslistheid, taakstrukturering, empatie, redeneringsvermoë en aanbiedingsvermoë (cf. Britz (1984) vir ' $n$ bespreking van die dimensies). Die dimensies dra elk dieselfde gewig.
Nadat al die beskikbare getuienis onder die verskillendes dimensies aangebring is, word die deelnemer se gedrag per dimensie aan die hand van die teikenpos beoordeel. Die volgende ordinale metingskaal word gebruik:

5 voldoen uitmuntend, gemeet teen die norm van ' $n$ senior afdelingsbestuurder

4 voldoen goed, gemeet teen die norm van 'n senior afdelingsbestuurder

3 voldoende, gemeet teen die norm van ' $n$ senior afdelingsbestuurder

2 nie heeltemal voldoende nie, gemeet teen die norm yan in senior afdelingsbestuurder

1 voldoen glad nie, gemeet teen die norm van ' $n$ senior afdelingsbestuurder

Hoewel dit nie hierbo so uiteengesit is nie, het 'n praktyk in die organisasie ontstaan dat die beoordelaars soms gebruik maak van tussenskale, byvoorbeeld 'n $2+$ wat net swakker as ' $n 3$ is, asook gesplete beoordelings, byvoorbeeld ' $n 3 / 2$ wa aandui dat die deelnemer verskillend ten opsigte van die gemete dimensie presteer het in twee oefeninge.

Met die oog op die statistiese verwerking van die beoordelings was dit nodig om ' $n$ numeriese waarde aan hierdie tussenbeoordelingsyfers te koppel (byvoorbeeld die 2+, soos hierbo verduidelik). Vir hierdie doel is' $n$ omskakelingstabel, opgestel deur De Bod (1980), gebruik. Sy tabel maak voorsiening vir die relatiewe waardes van elke moontlike beoordeling.

\section{Steekproef}

Die teikenpopulasie, vir die doeleindes van die huidige studie, het uit alle deelnemers aan die takseersentrum gedurende die tydperk Januarie 1992 tot Desember 1993 bestaan, naamlik 240 deelnemers. Daar is van trossteekproeftrekking gebruik gemaak, wat ' $n$ waarskynlikheidsteekproefnemingsmetode is. Die grootte van die steekproef, soos dit gerealiseer het in die aantal bruikbare vraelyste vir ontleding, was 91 .

\section{Meetinstrument en data-insameling}

Vir data-insamelingsdoeleindes is die finale beoordelings (per bestuursdimensie) van elke deelnemer verkry vanaf die waarnemerbeoordelingvorms.

Die meetinstrument wat in hierdie ondersoek gebruik is, is ' $n$ selfbeoordelingvraelys wat sowel voor as direk na afloop van die sentrum deur elke deelnemer voltooi is. In die vraelys word elkeen van die 13 bestuursdimensies gelys en elke dimensie omskryf (kyk Tabel 1 vir die omskrywings), Die deelnemer beoordeel dan, per bestuursdimensie, aan die hand van ' $n$ vyfpunt-metingskaal, die mate waarin hy van mening is dat sy bestuursvermoé aan dié van die teikenbestuursvlak voldoen.

Alvorens die vraelys voltooi is, het die toetsafnemer aan die deelnemers verduidelik dat die afneem van die vraelys slegs vir navorsingsdoeleindes is. Die toetsafnemer het ook verseker dat die deelnemers verstaan wat bedoel word met die poswaarde van die teikenbestuursvlak, naamlik die van ' $n$ senior afdelingsbestuurder. Hy het ook die omskryfde bestuursdimensies, wat in die vraelys gelys word, aan die deelnemers voorgelees en seker gemaak dat die deelnemets die omskrywing van elke dimensie verstaan.

\section{Die volgende instruksies verskyn op die vraelys:}

"Beoordeel $u$ eie bekwaamheid ten opsigte van die volgende dimensies: selfontwikkeling, inisiatief, deursettingsvermoë, analitiese vermoë, oordeelsvermoe, buigsaamheid, mensbenutting, beslistheid, taakstrukturering, empatie, redeneringsvermoë, aanbiedingsvermoë en beplanning en organisering.

Hierdie inligting word slegs vir navorsingsdoeleindes en vir $\mu$ eie persoonlike ontwikkeling gebruik. Met behulp van die skaal hieronder moet $u$ die toepaslike syfer merk wat $u$ olak van bevoegdheid sal aandui. Meet uself teen die standaarde wat gestel word vir ' $n$ senior afdelingsbestuurder of gelykwaardige depar- 
tementshoof. Voldoende beteken dat $u$ reeds oor die vaardigheid ten opsigte van ' $n$ betrokke dimensie beskik, soos verwag word van 'n senior afdelingsbestuurder:

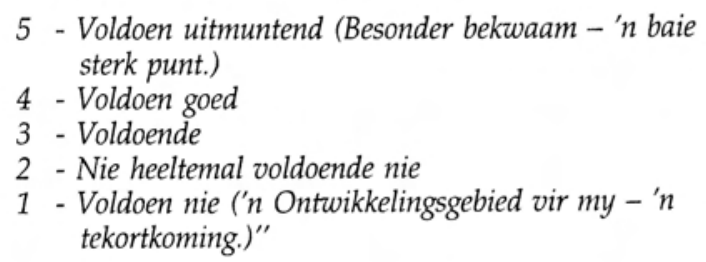

Die omskrywings van die dimensies wat op die selfbeoordelingvraelys, asook op die waarnemerbeoordelingvorms verskyn, word in Tabel 1 uiteengesit.

\section{Statistiese ontleding}

Die gemiddeldes, standaarafwykings, mediane en variasiebreedtes van die tellings is bereken. Vervolgens is die volgende prosedure gevolg om te bepaal of daar steun vir die gestelde postulaat en hipotese is: Die resultate van die voor-sentrum selfbeoordelings, na-sentrum selfbeoordelings en beoordelaartellings (dit wil sê die waargenome gesimuleerde bestuursvermoë), is geïnterkorreleer en die eiewaardes van die verkreë interkorrelasiematriks is met behulp van die PCA (Principal component analysis) subroetine bepaal. Daar is soveel faktore gepostuleer as wat daar eiewaardes groter as een was (Ford, MacCullum \& Tait, 1986; Kaiser, 1961). Vervolgens is die PFA (Principal factor analysis) subroetine van die BMDP4Mprogram gebruik en die verkreë faktormatriks na eenvoudige struktuur geroteer met behulp van die varimaks rotasie. Die doel met die varimaks rotasie is die minimalisering van die kompleksiteit van faktore deur die maksimering van die

TABEL 1

\section{OMSKRYWING VAN TAKSEERSENTRUMDIMENSIES}

1: Selfontwikkeling

2: Inisiatief
Blyke van bereidwilligheid om eie vermoëns/vaardighede te ontwikkel en homself daardeur beter toe te rus vir 'n senior bestuurspos.

Die vermoë, vindingrykheid en bereidwilligheid om nuwe gedagtes self na vore te bring, om sake aan die gang te sit of iets daaromtrent te doen sonder om daartoe aangepor hoef te word.

3: Deursettingsvermoë Die vermoë om met 'n taak te volhard en dit suksesvol deur te voer, nieteenstaande struikelblokke wat ondervind mag word.

4: Analitiese vermoë

Die vermoë om die implikasies van 'n situasie gou te snap, die relevante data te identifiseer en tot die grondoorsake van 'n probleem deur te dring.

5: Oordeelsvermoë

Die vermoë om tot logiese gevolgtrekkings te kom en gesonde verstand aan die dag te lê in die oplossing van probleme.

6: Buigsaamheid

Die bereidwilligheid om 'n eie standpunt te heroorweeg in die lig van ander se sienswyses.

7: $\quad$ Mensbenutting

Die vermoë om die bekwaamhede van ander in te span, en dit stelselmatig tot hoër doeltreffendheid te ontwikkel.

8: Beslistheid

Die vermoë om sonder huiwering beslissings te neem en die verantwoordelikheid daarvoor te aanvaar.

9: Taakstrukturering

Die vermoë om individue en groepe effektief te lei tot doelbereiking.

10: Empatie

Daadwerklike besorgdheid oor die behoeftes en gevoelens van ander, persoonlike warmte en aanmoediging.

11: Redeneringsvermoë

Die vermoë om spontaan met oortugiende en logiese argumente vorendag te kom om sodoende 'n doel te bereik.

12: Aanbiedingsvermoë

Die vermoë om deur middel van 'n voorbereide aanbieding konsepte so oor te dra dat ander se denkwyse daardeur beïnvloed word.

13: Beplanning en organisering Die vermoë om duidelike doelwitte te omlyn, en ordelik en sistematies die middele daartoe te mobiliseer variansie van die beladings van elke faktor (Tabacknick en Fidell, 1983). Die tellings is vervolgens gekategoriseer volgens die konstrukte waarop hulle die hoogste ladings het. Subtellings is vir elke faktor gevorm deur die items met hoë ladings op 'n faktor te sommeer, nadat die nodige refleksies gedoen is ten opsigte van die items met negatiewe ladings. Die subtellings is voorts geïnterkorreleer en weer aan ' $n$ hooffaktorontleding onderwerp. DIe getal faktore wat onttrek is, is weer eens volgens Kaiser (1961) se kriterium beraam en die verkreë faktormatriks is na 'n eenvoudige struktuur geroteer met behulp van die "Direct Oblimin" rotasie, wat 'n skuinsrotasie is. Ten einde vas te stel of the voor-sentrum selfbeoordelings die gesimuleerde bestuursvermoë soos deur die beoordelaars waargeneem, kan voorspel, is 'n regressie-ontleding onderneem. Die betroubaarhede van die drie stelle metings is bereken aan die hand van Cronbach se alfa koëffisiënt (vgl. Cronbach, 1984, p. 169-171).

\section{RESULTATE}

Beskrywende statistiek

Die gemiddelde ouderdom van die respondente is 39 jaar $(\bar{X}=39,20 ;$ mediaan $=41 ;$ modus $=42)$. Die huistaal en geslag van die respondente is nie ontleed nie, omdat die meerderheid respondente Afrikaanssprekende mans is. ' $n$ Rassegroepontleding toon dat al die respondente wit mans en vroue is.

Die beskrywende statistiek van die voor-sentrum selfbeoordelings, na-sentrum selfbeoordelings en beoordelaartellings word per bestuursdimensie in Tabel 2 getoon. 
TABEL 2

BESKRYWENDE STATISTIEK

\begin{tabular}{|c|c|c|c|c|c|c|c|}
\hline & $\begin{array}{l}\text { Voor-sentrum } \\
\text { selfbeoordelings }\end{array}$ & Gemiddeld & $\mathrm{SA}$ & Mediaan & Maksimum & Minimum & $\begin{array}{l}\text { Variasie- } \\
\text { breedte }\end{array}$ \\
\hline $\mathrm{X} 1$ & Selfontwikkeling & 88,297 & 45,266 & 100 & 130 & 9 & 171 \\
\hline$\times 2$ & Inisiatief & 101,209 & 41,415 & 100 & 150 & 20 & 130 \\
\hline$x_{3}$ & Deursettingsvermoë & 100,286 & 42,289 & 100 & 180 & 20 & 160 \\
\hline$\times 4$ & Analitiese vermoë- & 93,033 & 43,479 & 100 & 180 & 20 & 160 \\
\hline $\mathrm{X} 5$ & Oordeel & 91,538 & 36,910 & 100 & 180 & 20 & 160 \\
\hline$x_{6}$ & Buigsaamheid & 102,747 & 40,581 & 100 & 180 & 40 & 140 \\
\hline $\mathrm{X} 7$ & Mensbenutting & 78,308 & 43,810 & 100 & 180 & 20 & 160 \\
\hline$x_{8}$ & Beslistheid & 102,308 & 41,502 & 100 & 180 & 20 & 160 \\
\hline$x_{9}$ & Taakstrukturering & 83,187 & 42,240 & 100 & 150 & 20 & 130 \\
\hline $\mathrm{X} 10$ & Empatie & 101,429 & 44,361 & 100 & 180 & 20 & 160 \\
\hline $\mathrm{X} 11$ & Redeneringsvermoë & 91,868 & 44,144 & 100 & 180 & 20 & 160 \\
\hline $\mathrm{X} 12$ & Aanbiedingsvermoë & 75,934 & 45,922 & 40 & 150 & 20 & 130 \\
\hline \multirow[t]{3}{*}{$\mathrm{X} 13$} & Beplanning en Organisering & 89,879 & 42,145 & 100 & 180 & 9 & 171 \\
\hline & GEMIDDELD & 92,309 & 45,620 & 95 & 169 & 20 & 153 \\
\hline & $\begin{array}{l}\text { Na-sentrum } \\
\text { selfbeoordelings }\end{array}$ & Gemiddeld & SA & Mediaan & Maksimum & Minimum & $\begin{array}{l}\text { Variasie- } \\
\text { breedte }\end{array}$ \\
\hline $\mathrm{Y} 1$ & Selfontwikkeling & 59,791 & 40,528 & 40 & 150 & 9 & 141 \\
\hline $\mathrm{Y} 2$ & Inisiatief & 68,363 & 35,701 & 86 & 180 & 9 & 171 \\
\hline$Y_{3}$ & Deursettingsvermoë & 78,352 & 33,449 & 100 & 150 & 20 & 130 \\
\hline Y4 & Analitiese vermoë & 66,813 & 35,317 & 86 & 150 & 20 & 130 \\
\hline Y5 & Oordeel & 79,516 & 30,644 & 100 & 150 & 20 & 130 \\
\hline Y6 & Buigsaamheid & 86,692 & 27,387 & 100 & 150 & 20 & 130 \\
\hline Y7 & Mensbenutting & 68,374 & 34,640 & 66 & 150 & 20 & 130 \\
\hline Y8 & Beslistheid & 81,703 & 33,449 & 100 & 150 & 9 & 141 \\
\hline Y9 & Taakstrukturering & 63,110 & 33,174 & 40 & 150 & 9 & 141 \\
\hline Y10 & Empatie & 76,154 & 32,475 & 100 & 150 & 20 & 130 \\
\hline Y11 & Redeneringsvermoë & 77,560 & 34,757 & 100 & 150 & 20 & 130 \\
\hline $\mathrm{Y} 12$ & Aanbiedingsvermoé & 67,835 & 37,691 & 66 & 150 & 9 & 141 \\
\hline \multirow[t]{3}{*}{ Y13 } & Beplanning en organisering & 66,374 & 35,619 & 40 & 150 & 20 & 130 \\
\hline & GEMIDDELD & 72,357 & 34,218 & 79 & 152 & 16 & 137 \\
\hline & Beoordelaartellings & Gemiddeld & SA & Mediaan & Maksimum & Minimum & $\begin{array}{l}\text { Variasie- } \\
\text { breedte }\end{array}$ \\
\hline $\mathrm{Z1}$ & Selfontwikkeling & 43,011 & 20,408 & 40 & 86 & 20 & 66 \\
\hline $\mathrm{Z} 2$ & Inisiatief & 37,890 & 18,774 & 40 & 100 & 20 & 80 \\
\hline $\mathrm{Z3}$ & Deursettingsvermoë & 76,703 & 23,548 & 86 & 100 & 20 & 80 \\
\hline $\mathrm{Z} 4$ & Analitiese vermoë & 44,505 & 18,846 & 40 & 100 & 20 & 80 \\
\hline $\mathrm{Z} 5$ & Oordeel & 98,681 & 3,480 & 100 & 100 & 86 & 14 \\
\hline Z6 & Buigsaamheid & 99,538 & 1,432 & 100 & 100 & 88 & 12 \\
\hline $\mathrm{Z7}$ & Mensbenutting & 50,308 & 17,502 & 40 & 100 & 20 & 80 \\
\hline $\mathrm{Z} 8$ & Beslistheid & 98,000 & 6,015 & 100 & 100 & 66 & 34 \\
\hline $\mathrm{Z9}$ & Taakstrukturering & 45,165 & 20,067 & 40 & 86 & 20 & 66 \\
\hline Z10 & Empatie & 46,770 & 16,069 & 40 & 100 & 40 & 60 \\
\hline Z11 & Redeneringsvermoë & 69,033 & 22,308 & 66 & 100 & 20 & 80 \\
\hline $\mathrm{Z} 12$ & Aanbiedingsvermoë & 61,956 & 24,609 & 66 & 100 & 20 & 80 \\
\hline $\mathrm{Z13}$ & Beplanning en organisering & 54,637 & 20,692 & 40 & 100 & 20 & 80 \\
\hline & GEMIDDELD & 63,554 & 16,442 & 61 & 98 & 35 & 62 \\
\hline
\end{tabular}

Uit die inligting vervat in Tabel 2 kan afgelei word dat die gemiddelde selfbeoordelingtellings (sowel voor-sentrum selfbeoordelings as na-sentrumbeoordelings) hoër as die beoordelaartellings is. Die gemiddelde voor-sentrumbeoordelingtellings is weer hoër as die na-sentrum selfbeoordelingtellings.

Dieselfde patroon word waargeneem as die onderskeie standaardafwykings en mediane bestudeer word. Die variasiebreedte van die voor-sentrum selfbeoordelings is groter as dié van die na-sentrum selfbeoordelings. Die variasiebreedte van die beoordelaartellings is kleiner as dié van die voor- en na-sentrum selfbeoordelings. Die beoordelaars was dus geneig om nie die volle wydte van die beoordelaarskaal te gebruik nie, terwyl die deelnemers meer geneig was om die volle beoordelingskaal te gebruik. Uit Tabel 1 kan gesien word dat die mediaan van die voor-sentrum selfbeoordelings ten opsigte van 12 van die 13 dimensies gelyk is aan 100 .' $n$ Telling van 100 is gelyk aan die omgeskakelde punt (volgens omskakelingstabel van De Bod, 1980) wat terugherlei na ' $n 3$ (voldoende) op die skaal wat op die vraelys gebruik is. Op grond hiervan blyk dit dat $50 \%$ van die deelnemers aan die begin van die selfbeoordelingsproses van mening was dat hulle aan die gestelde bestuursnorm voldoen of meer voldoen, terwyl $50 \%$ van die deelnemers van mening was dat hulle nie aan die gestelde bestuursnorm voldoen nie.

\section{Faktorontleding}

Ten einde te bepaal of the voor-sentrum selfbeoordelingtellings (X-tellings), na-sentrum selfbeoordelingtellings ( $Y$ tellings) en beoordelaartellings (Z-tellings) ten opsigte van die 13 bestuursdimensies, soos vroeër in die artikel omskryf, onderling saamhang, is die 39 tellings geinterkorreleer en aan 
'n hooffaktorontleding onderwerp. Die doel hiervan was om beter insig in die onderliggende korrelasiestruktuur van die datastel te verkry.

Met die eersteorde-faktorontleding is agt faktore met eiewaardes groter as een onttrek.

'n Ontleding van die agt faktore toon die volgende:

Faktor 1: Faktor 1 het slegs beladings op sekere $\mathrm{X}$ - veranderlikes (voor-sentrum selfbeoordelings), naamlik: $X_{2}, X_{3}, X_{4}, X_{5}, X_{8}, X_{9}, X_{11}$ en $X_{13}$

Faktor 2: Faktor 2 het slegs beladings op sekere $Z$ veranderlikes (beoordelaarstellings), naamlik: $Z_{1}, Z_{2}, Z_{3}, Z_{4}$, $Z_{7}, Z_{8}, Z_{9}, Z_{11}, Z_{12}$ en $Z_{13}$

Faktor 3: Faktor 3 het slegs beladings op die sekere $Y$ veran- derlikes (na sentrum selfbeoordelings), en wel op $Y_{2}, Y_{3}, Y_{4}, Y_{5}, Y_{7}, Y_{8}, Y_{9}$ en $Y_{13}$

Faktor 4: Faktor 4 het beladings op twee $X$ veranderlikes en een $Y$ veranderlike, naamlik: $X_{6}, X_{7}, X_{10}, Y_{10}$

Faktor 5: Faktor 5 het beladings op enkele $X$ en $Y$ veranderlikes, naamlik: $X_{12}, Y_{11}, Y_{12}$.

Faktor 6: Faktor 6 het beladings op een $X$ en een $Y$ veranderlike, naamlik: $X_{1}$ en $Y_{1}$.

Faktor 7: Faktor 7 het beladings op $Z$ veranderlikes, naamlik: $Z_{5}, Z_{6}$ en $Z_{10}$. (dus eintlik nie faktor nie)

Faktor 8: Faktor 8 het beladings op 'n enkele $Y$ telling, naamlik $\mathrm{Y}_{6}$.

Die agt subtellings is voorts geïnterkorreleer en aan 'n tweedeorde-faktorontleding onderwerp. Die interkorrelasiematriks van die agt subtellings word in Tabel 3 weergegee.

TABEL 3

INTERKORRELASIEMATRIKS TEN OPSIGTE VAN DIE AGT SUBTOETSTELLINGS

\begin{tabular}{|c|c|c|c|c|c|c|c|c|}
\hline & $\begin{array}{c}\text { FAKTOR } 1 \\
(X)\end{array}$ & $\begin{array}{l}\text { FAKTOR } 2 \\
\text { (Z) }\end{array}$ & $\begin{array}{l}\text { FAKTOR } 3 \\
(Y)\end{array}$ & $\begin{array}{c}\text { FAKTOR } 4 \\
(\mathrm{X})\end{array}$ & $\begin{array}{c}\text { FAKTOR } 5 \\
(X \text { en } Y)\end{array}$ & $\begin{array}{c}\text { FAKTOR } 6 \\
(X \text { en } Y)\end{array}$ & $\begin{array}{c}\text { FAKTOR } 7 \\
(X \text { en } Y)\end{array}$ & $\begin{array}{c}\text { FAKTOR } 8 \\
(Y)\end{array}$ \\
\hline FAKTOR $1(X)$ & 1,0000 & & & & & & & \\
\hline FAKTOR 2 (Z) & 0,2571 & 1,0000 & & & & & & \\
\hline FAKTOR $3(Y)$ & $\underline{0,6597}$ & $\underline{0,3125}$ & 1,0000 & & & & & \\
\hline FAKTOR $4(X)$ & $\underline{0,5802}$ & 0,0594 & $\underline{0,3993}$ & 1,0000 & & & & \\
\hline FAKTOR $5(X$ en $Y)$ & $\underline{0,5692}$ & $\underline{0,3960}$ & $\underline{0,6212}$ & $\underline{0,4007}$ & 1,0000 & & & \\
\hline FAKTOR 6 ( $X$ en $Y)$ & $\underline{0,4882}$ & 0,2092 & $\underline{0,5371}$ & $\underline{0,3835}$ & $\underline{0,4109}$ & 1,0000 & & \\
\hline FAKTOR 7 ( $X$ en $Y)$ & $-0,2780$ & $-0,0413$ & $\underline{-0,3091}$ & $-0,0567$ & $-0,1890$ & $\underline{-0,3050}$ & 1,0000 & \\
\hline FAKTOR $8(\mathrm{~N})$ & $\underline{0,4614}$ & 0,1868 & $\underline{0,5381}$ & $\underline{0,4191}$ & $\underline{0,3782}$ & $\underline{0,4372}$ & $-0,0862$ & 1,0000 \\
\hline
\end{tabular}

Uit Tabel 3 is dit duidelik dat die $X$ tellings (voor-sentrum selfbeoordelings) betekenisvol met die $Y$ tellings (na-sentrum selfbeoordelings) korreleer. Die $\mathrm{X}$ tellings korreleer egter nie betekenisvol met die $Z$ tellings (beoordelaartellings) nie. Die $Z$ tellings korreleer egter betekenisvol met die $\mathrm{Y}$ tellings.

Met die tweedeorde-faktorontleding is drie faktore onttrek. Die eiewaardes van dié faktore word in Tabel 4 weergegee.

TABEL 4

FAKTORE MET EIGENWAARDES >1 UIT DIE TWEEDEORDE-FAKTORONTLEDING

\begin{tabular}{ccccc}
\hline & & \multicolumn{2}{c}{$\begin{array}{c}\text { Kumulatiewe proporsie } \\
\text { van variansie }\end{array}$} & \\
\cline { 3 - 4 } Faktor & eigenwaarde & $\begin{array}{c}\text { in } \\
\text { dataruimte }\end{array}$ & $\begin{array}{c}\text { in } \\
\text { faktorruimte }\end{array}$ & $\begin{array}{c}\text { Carmine } \\
\text { se Theta }\end{array}$ \\
\hline 1 & 3,6812 & 0,4601 & 0,6447 & 0,8324 \\
2 & 1,0165 & 0,5878 & 0,8227 & \\
3 & 1,0121 & 0,7137 & 1,000 & \\
\hline
\end{tabular}

Uit die bostaande tabel word gemerk dat die eerste faktor die grootste persentasie van die variansie van die subtellings verklaar, naamlik $46,01 \%$. Die drie faktore verklaar $71,37 \%$ van die variansie van die subtoetstellings.

Die geroteerde faktormatriks ten opsigte van die tweedeordefaktore verskyn in Tabel 5 (beladings van kleiner as 0,25 is met 0 vervang):
TABEL 5

MATRIKS VAN GEROTEERDE TWEEDEORDEFAKTORE

\begin{tabular}{lccc}
\hline SUBTOETS & FAKTOR 1 & FAKTOR II & FAKTOR III \\
\hline 1 (X-tellings) & $\underline{0,621}$ & 0,000 & 0,000 \\
2 (Z-tellings) & 0,000 & $\underline{0,628}$ & 0,000 \\
3 (Y-tellings) & $\underline{0,407}$ & 0,000 & $\underline{-0,301}$ \\
4 (X-tellings) & $\underline{0,905}$ & $\underline{0,393}$ & 0,000 \\
5 (X en Y tellings) & $\underline{0,336}$ & $\underline{0,520}$ & 0,000 \\
6 (X en Y tellings) & $\underline{0,396}$ & 0,000 & $\underline{-0,315}$ \\
7 (X en Y tellings) & 0,000 & 0,000 & $\underline{-0,705}$ \\
8 (Y-telling) & $\underline{0,508}$ & 0,000 & 0,000 \\
\hline
\end{tabular}

Die faktore in Tabel 5 is geïnterpreteer in die lig van hulle faktorbeladings. Volgens Nunnally $(1978$, p. 357) kan faktorbeladings hoër as 0,30 as beduidend en interpreteerbaar beskou word ten opsigte van steekproewe van grootte 100. Gedagtig hieraan kan die volgende algemene afleidings uit die resultate in Tabel 5 gemaak word:

\section{Faktor I}

Die inhoude van die items wat hoog laai op Faktor I het hoofsaaklik betrekking op die na-sentrum selfbeoordelingtellings en meer spesifiek: $Y_{1}, Y_{2}, Y_{3}, Y_{4}, Y_{5}, Y_{6}, Y_{7}, Y_{8}, Y_{9}, Y_{11}$, $Y_{12}$ en $Y_{13}$. Faktor I kan dus oorkoepelend as beskrywend van die na-sentrum selfbeoordelingtellings beskou word. 


\section{Faktor II}

Faktor II se inhoud het betrekking op die X-tellings (voorsentrum selfbeoordelings). Die inhoud van die tellings verteenwoordig hoofsaaklik al die voor-sentrum selfbeoordelingdimensies. Faktor II kan dus oorkoepelend as beskrywend van die voor-sentrum selfbeoordelingtellings beskou word.

\section{Faktor III}

Die inhoude van die items wat hoog laai op Faktor III het hoofsaaklik betrekking op die Z-tellings (beoordelaartellings) en meer spesifiek: $Z_{5}, Z_{6}$ en $Z_{10}$. Faktor III kan dus oorkoepelend as beskrywend van die beoordelaartellings beskou word.

Voorts kan uit die interkorrelasiematriks van die drie tweedeorde-faktore, soos aangetoon in Tabel 6, tot die gevolgtrekking gekom word dat slegs Faktor I en Faktor II betekenisvol met mekaar korreleer (korrelasies $\geq 0,30$ word as beduidend en interpreteerbaar beskou). Hieruit kan dus afgelei word dat die X-tellings betekenisvol met die Y-tellings korreleer.

TABEL 6

INTERKORRELASIEMATRIKS VAN DIE DRIE TWEEDEORDE-FAKTORE

\begin{tabular}{lccc}
\hline & FAKTOR 1 & FAKTOR II & FAKTOR III \\
\hline FAKTOR I & 1,000 & & \\
FAKTOR II & $\underline{0,430}$ & 1,000 & \\
FAKTOR III & $-0,355$ & $-0,329$ & 1,000 \\
\hline
\end{tabular}

\section{Regressie-ontleding}

Ten einde 'n persoon se gesimuleerde bestuursvermoë (z tellings) te voorspel aan die hand van die voor-sentrus selfbeoordelingtellings (X-tellings), is ' $n$ meervoudige regre: sie-ontleding (soos beskryf in Tabachnick \& Fidell, 1983) va die X-tellings op die Z-tellings onderneem.

Die 13 voor-sentrum selfbeoordelingtellings (X-tellings) gebruik as voorspellers. Die saamgestelde Z-telling (Faktor I] is gebruik as afhanklike veranderlike.

Die regressiemodel met al die veranderlikes sien as volg da uit:

$$
\begin{aligned}
\hat{Z}= & 376,172+0,07 X_{1}-0,53 X_{2}+0,18 X_{3}+0,3 X_{4}-0,82 X_{5}+0,09 X_{6}- \\
& 0,44 X_{7}+0,92 X_{8}+0,08 X_{9}-0,42 X_{10}+0,10 X_{11}+1,16 X_{12}+ \\
& 0,40 X_{13}
\end{aligned}
$$

Slegs een regressiekoëffisiënt was egter statisties beduidend, wete die van $X_{12}$. Die regressiemodel met slegs veranderlil $X_{12}$ as voorspeller is as volg:

$\hat{Z}=353,98+1,14 X_{12}$

Die ongestandaardiseerde regressiekoëffisiënte, gestandaarc seerde regressiekoëffisiënte, $t$-waardes ten opsigte van $d$ regressiekoëffisiënte en vlak van beduidenheid van $d$ regressiegewigte, word in Tabel 7 aangedui.

Uit Tabel 7 kan gesien word dat veranderlike $Z_{12}$ die groots bydrae maak tot die verklaring van die variasie van $Z$.

\section{Betroubaarheid}

Die betroubaarheid van die $\mathrm{X}, \mathrm{Y}$ en $\mathrm{Z}$ tellings is aan die har van Cronbach se alfa koëffisiënt bereken. Cronbach se al

\begin{tabular}{|c|c|c|c|c|}
\hline & $\begin{array}{l}\text { Ongestandaardiseerde } \\
\text { regressie koëffisiënte }\end{array}$ & $\begin{array}{l}\text { Gestandaardiseerde } \\
\text { regressiekoëffisiënte }\end{array}$ & $\begin{array}{l}\text { t-waardes ten opsigte van } \\
\text { regressiekoëffisiënte }\end{array}$ & $\begin{array}{l}\text { Beduidenheidsvlakke van } \\
\mathrm{t} \text {-waardes }\end{array}$ \\
\hline $\mathrm{X} 1$ & 0,069 & 0,361 & 0,19 & 0,849 \\
\hline $\mathrm{X} 2$ & $-0,529$ & 0,472 & $-1,12$ & 0,266 \\
\hline $\mathrm{X} 3$ & 0,181 & 0,440 & 0,41 & 0,681 \\
\hline$X 4$ & 0,032 & 0,440 & 0,07 & 0,942 \\
\hline X5 & $-0,824$ & 0,601 & $-1,37$ & 0,174 \\
\hline$X_{6}$ & 0,088 & 0,398 & 0,22 & 0,826 \\
\hline X7 & $-0,438$ & 0,422 & $-1,04$ & 0,303 \\
\hline X8 & 0,923 & 0,488 & 1,89 & 0,062 \\
\hline X9 & 0,080 & 0,496 & 0,16 & 0,872 \\
\hline X10 & $-0,423$ & 0,325 & $-1,30$ & 0,197 \\
\hline X11 & 0,095 & 0,435 & 0,22 & 0,829 \\
\hline X12 & 1,163 & 0,356 & 3,26 & $0,002^{*}$ \\
\hline X13 & 0,396 & 0,494 & 0,8 & 0,425 \\
\hline
\end{tabular}

TABEL 7

MEERVOUDIGE REGRESSIE KOËFFISIËNTE

Meervoudige R: 0,4190

$\mathrm{R}^{2} \quad: 0,1755$

Aangepaste $\mathrm{R}^{2}: 0,1663$

Standaardfout : 113,6423

koëffisiënt is 'n maatstaf van interne konsekwentheid. Hierdie indeks dui dus die mate aan waarin al die times dieselfde eienskap (in hierdie geval bestuursvermoë) meet. Die betroubaarhede is bereken volgens die Kuder-Richardson-20 formule (vgl. Schepers, 1992, p. 99). Koëffisiënt alfa is gelyk aan 0,923 ten opsigte van die voor-sentrum selfbeoordelingtellings, 0,91 ten opsigte van die na-sentrum selfbeoordelingtellings, en 0,824 ten opsigte van die beoordelaartellings.

Hierdie waardes lui daarop dat die betroubaarhede van die voor- en na-sentrum selfbeoordelingstellings hoër is as dié van die beoordelaartellings. Vir navorsingsdoeleindes word c beoordelaartellings egter nogtans as betroubaar beskou, aa gesien koëffisiënt alfa deurgaans hoër as 0,8 is.

\section{BESPREKING EN GEVOLGTREKKING}

Uit die resultate gerapporteer in Tabel 2 is dit duidelik dat c deelnemers geneig was om hulself meer positief te beoordeel wat uit hul waargenome gesimuleerde bestuursvermoë bl Die voor-sentrum selfbeoordeling is ook deurgaans hoër die na-sentrum selfbeoordelings. Hierdie tendens beves 
Smit (1986, p. 103) se bevinding dat deelnemers aan 'n takseersentrum geneig is om hulself by die aanvang van die sentrum hoër aan te slaan as na voltooiing van die simulasieoefeninge. Dit bevestig ook Strube et al. (1986) en Trope (1980) se aanname dat individue 'n positiewe beeld ten opsigte van hulself huldig en geneig is om hulself voordelig voor te stel.

Uit die interkorrelasiematriks ten opsigte van die agt eersteorde-faktore (Tabel 3) asook die drie tweedeorde-faktore (Tabel 6) kan die afleiding gemaak word dat die voor-sentrum selfbeoordelings en na-sentrum selfbeoordelings beduidend met mekaar korreleer. Daar is dus steun vir Postulaat 2, naamlik dat daar 'n statisties beduidende verband tussen selfbeoordeling van bestuurspotensiaal, voor deelname aan 'n takseersentrum, en self beoordeling van bestuurspotensiaal, na deelname aan ' $n$ takseersentrum bestaan.

Ten opsigte van die meervoudige regressie ontleding is dit duitdelik dat net een van die voorspellers, te wete aanbiedingsvermoë, 'n statistiese beduidende koëffisiënt opgelewer het. Waarom juis aanbiedingsvermoë na vore gekom het as 'n voorspeller, kan wees omdat deelnemers moontlik gereeld terugvoer in die verband kry, of omdat die vermoë duidelik waarneembaar is (dit verg dus nie 'n groot mate van insig om 'n korrekte voorspelling te maak nie). Daar is dus slegs gedeeltelik steun vir Postulaat 1, naamlik dat selfbeoordeling van bestuurspotensiaal, voor deelname aan 'n takseersentrum, gebruik kan word om waargenome gesimuleerde bestuursvermoë, soos beoordeel in 'n takseersentrum, te voorspel.

Die oorspronklike doel met hierdie studie was om te bepaal of daar ' $n$ verband bestaan tussen selfbeoordeling en waargenome gesimuleerde bestuursvermoë. In terme van die gestelde doel en getoetste postulate blyk dit dat selfbeoordelingsresultate nie noodwendig ' $n$ voorspeller van waargenome gesimuleerde bestuursvermoë is nie. Organisasies wat die takseersentrum hoofsaaklik vir keuringsdoeleindes gebruik kan dus nie 'n persoon se takseersentrumresultate met selfbeoordelingtellings vervang nie.

Die ontwikkelingsentrum konsep, soos vroeër in die studie verduidelik, kan egter met groot vrug verder ondersoek en gebruik word, omdat daar tydens dié tipe sentrum meer tyd en aandag geskenk word aan terugvoering aan die deelnemers oor hul waargenome bestuursvermoë en -potensiaal. Tydens die ontwikkelingsentrum kan selfbeoordelings dus vergelyk word met die waargenome beoordelaartellings en tydens terugvoersessies gebruik word om die individu tot groter selfinsig ten opsigte van bestuursvermoë en bestuurspotensiaal te lei.

'n Moontlike punt van kritiek teen hierdie studie is die feit dat kulturele verskille nie in ag geneem is nie. Soos vroeër in die artikel uitgewys, toon Farh et al. (1991) dat Taiwanese werknemers nederig-bevooroordeeld is. Die moontlikheid is dus nie uitgesluit dat ander rassegroepe in Suid-Afrika verskillende resultate mag oplewer nie. Hierdie aspek kan sinvol verder ondersoek word. Daar bestaan dan ook 'n tekort aan Suid-Afrikaanse studies oor die verskillende toepassingsmoontlikhede van selfbeoordeling in die menslike hulpbronbestuursomgewing. Die waarde van selfbeoordeling kan voorts in die opleiding en ontwikkeling van werknemers ondersoek word, aangesien die mate van selfinsig wat deur die beoordelingsproses ontstaan, moontlik kan bydra tot die verryking van leerervarings. Die verband tussen selfbeoordeling en prestasiemotivering kan ook verder ondersoek word.

\section{VERWYSINGS}

Auld, D. (1990). Remuneration. In J.A. Slabbert, J.J. Prinsloo, \& W. Backer (Eds.). Managing industrial relations in South Africa. Pretoria: Digma.

Appelbaum, S.H., Kay, F., \& Shapiro, B.T. (1989). The assessment centre is not dead! How to keep it alive and well, Journal of Management Development, 8(5), 51-56.
Augustyn, J.C. \& Van Wyk, A.J. (1988). Die sestien persoonlikheidsfaktorvraelys (16PF) as hulpmiddel by die takseersentrum. Tydskrif vir Bedryfsielkunde, 14(2), 25-27.

Blanksby, M. \& Iles, P.A. (1990). Recent development in assessment theory, practice and operation. Personnel Review, 19(6), 33-44.

Boehm, V. (1982). Assessment centres and management development. In K.M. Rowland \& G.R. Ferris (Eds.). Personnel Management. Newton, MA: Allyn \& Bacon, 327362.

Borman, W. (1974). The ratings of individuals in organizations. An alternative approach. Organizational Behavior and Human Performance, 12, 279-284.

Bradley, G.W. (1978). Self-serving biases in the attribution process: a re-examination of the fact or fiction question. Journal of Personality and Social Psychology, 36, 56-71.

Bray, D.W., Campbell, R.J. \& Grant, D.L. (1974). Formative years in business: a long term ATET study of managerial lives. New York: Wiley-Interscience.

Britz, P.J. (1984). Die validering van ' $n$ bestuursbeoordelingsentrum. Ongepubliseerde Ph.D-proefskrif, Universiteit van Pretoria.

Brown, J.D. (1990). Evaluating one's abilities: shortcuts and stumbling blocks on the road to self-knowledge. Journal of Experimental Psychology, 26, 149-167.

Charoux, E. (1991). Assessment centres: a partial but objective look. Human Resource Management, 7(2), 28-29.

Cronbach, L.J. (1984). Essentails of psychological testing (4th ed.). New York: Harper \& Row.

De Bod, A.D. (1980). Tydoriëntasie as 'n fundamentele konsep in bestuursgedrag en bestuurstalent. Ongepubliseerde magisterverhandeling. Randse Afrikaanse Universiteit.

Dukes, J.A. (1988). Assessing management people. New York: Routledge Nichols.

Dulewicz, V. (1991). Improving assessment centres. Personnel Management, 23(6), 50-53.

De Plooy, G. (1984). What's new about assessment centres. IPM Journal, 3(1), 12-14.

Farh, J.L., Dobbins, G.H. \& Cheng, B.S. (1991). Cultural relativity in action: a comparison of self-ratings made by Chinese and US workers, Personnel Psychology, 44, 129147.

Ford, J.K., Mac Callum, R.C. \& Tait, M. (1986). The application of exploratory factor analysis in applied psychology: a critical review and analysis. Personnel Psychology, 39, 291314.

Furnham, A. \& Springfield, P. (1993). Personality and work performance: Myers-Briggs type indicator correlates of managerial performance in two cultures. Personality and Individual Differences, 14, 145-153.

Furnham, A. \& Springfield, P. (1994). Congruence of self and subordinate ratings of managerial practices as a correlate of supervisor evaluation. Journal of Occupational and Organizational Psychology, 67, 57-67.

Griffiths, P. \& Allen, B. (1987). Assessment centres: breaking with tradition. Journal of Management Development, 6(1), 18-29.

Guilford, J.P. (1973). Fundamental statistics in psychology and education. London: McGraw-Hill.

Harris, M.M., \& Schaubroeck, J. (1988). A meta-analysis of self-supervisor, self-peer, and peer-supervisor ratings. Personnel Psychology, 41, 43-62.

Heneman, H.G. (1980). Self-assessment: a critical analysis. Personnel Psychology, 33, 297-300.

Iles, P. (1992). Centres of excellence? Assessment and development centres, managerial competence and human resource strategies. British Journal of Management, 3, 79-90.

Kaiser, H.F. (1961). A note of Guttman's lower bound for the number of common factors. British Journal of Mathematical and Statistical Psychology, 14, 1.

Keel, S.B., Cochran, D.S., Arnett, K. \& Arnold, D.R. (1989). AC's are not just for the big guys. Personnel Administrator, 34(5), 98-101.

Kriek, H.J. (1989). Culture fairness of the assessment centre. IPM Journal, 7(12), 27-29.

Kriek, H.J. (1991). Die bruikbaarheid van die takseersentrum: 
'n oorsig van resente literatuur, Tydskrif vir Bedryfsielkunde, 17(3), 34-37.

Kriek, H.J., Hurst, D.N., \& Charoux, J.A.E. (1994). The assessment centre: testing the fairness hypothesis. Tydskrif vir Bedryfsielkunde, 20(2), 21-25.

Levine, E.L. (1980). Introductory remarks for the symposium "Organizational applications of self appraisal and self assessment: another look". Personnel Psychology, 33, 259262.

Levine, E.L., Flory, A. \& Ash, R.A. (1977). Self-assessment in personnel selection. Journal of Applied Psychology, 62, 428435.

Mabey, B. (1989). The majority of large companies use occupational tests. Guidance and Assessment Review, 5(3), 1-4.

Mabe, P.A. \& West, J.G. (1982). Validity of self-evaluation of ability: a review and meta-analysis, Joumal of Applied Psychology, 67(3), 280-296.

MacDonald, D.R. (1988). Greater results from your assessment center. Training and Development Journal, 42(2), 50-51.

Meyer, H.H. (1977). The annual performance review discussion: making it constructive. Personnel Journal, 56, 508-511,

Munchus, G., \& McArthur, B. (1991) Revising the historical use of the assessment centre in management selection and development. Joumal of Management Development, 10(1), 513 .

Nunnally, J.C. (1978). Psychometric theory. New York: McGrawHill.

Pietersen, H.J. (1990). Die voorspellingswaarde van die takseersentrum. Tydskrif vir Bedryfsielkunde, 16(3), 24-26.

Pietersen, H.J. (1992). Die waarde van die takseersentrum: 'n repliek. Tydskrif vir Bedryfsielkunde, 18(1), 20-22.

Rayner, I. \& Goodge, P. (1988), New techniques in assessment centres: LRT's experience. Joumal of Management Development, 7(4), 21-30.

Rodger, D. \& Mabey, C. (1987). BT's leap forward from assessment centres. Personnel Management, 19(7), 32-35.

Sackett, P.R., \& Ryan, A.M. (1985). A review of recent assessment centre research. Assessment Centres and Management Development, 4(4), 13-27.

Schepers, J.M. (1992). Toetskonstruksie: teorie en praktyk. Johannesburg: RAU-Drukpers.

Shore, T.H., Shore, L.M. \& Thomton, G.C. (1992). Construct validity of self- and peer evaluations of performana dimensions in an assessment center. Journal of Appue Psychology, 77(1), 42-54,

Smit, D.W. (1986). Takseersentrums: 'n toepassing van volwassa en ervaringsleerteorie. Ongepubliseerde magisterskrips Randse Afrikaanse Universiteit.

Snyder, M.L., Stephan, W.G. \& Rosenfield, D. (1976). Egotis and attribution. Joumal of Personality and Social Psychologi 33, 435-441.

Spangenberg, H.H. (1991). New guidelines and ethic-d considerations for assessment centre operations. IPM Journal, 9(10), 29-34.

Spangenberg, H.H., Esterhuyse, J.J., Visser, J.H. \& Brieden hann, J.E. (1989). Validation of an assessment centr against BARS: an experience with performance related criteria. Tydskrif vir Bedryfsielkunde, 15(2), 1-10.

Strube, M.J., Lott, C.L., Le-Xuân-Hy, G.M., Oxenberg, J. \& Deichmann, A.K. (1986). Self-evaluation of abilitiee accurate self-assessment versus biased self-enhance: ment. Journal of Personality and Social Psychology, 51, 16-25

Tabachnick, B.G., \& Fidell, L.S. (1983), Using multivariate statistics. New York: Harper \& Row.

Task Force on Assessment Centre Guidelines. (1989) Guidelines and ethical considerations for assessment center operations. Public Personnel Managenient, 18(4), 547-470.

Taylor, S.E. \& Brown, J.D. (1988). Illusion and well-being: a social psychological perspective on mental health. Psycho. logical Bulletin, 103, 193-210.

Thomton, G.C. (1968). The relationship between supervisory and self-appraisals in executive performance. Personne. Psychology, 21, 445-455.

Thornton, G.C. (1980). Psychometric properties of selfappraisal and job petformance. Personnel Psychology, 33, 263-271.

Thornton, G.C. \& Byham, W.C. (1982). Assessment centres ana managerial performance. New York: Academic Press.

Trope, Y. (1980). Self-assessment, self-enhancement and task preference. Joumal of Experimental Social Psychology, 16 116-129.

Woodruffe, C. (1990). Assessment centres: identifying anc developing competence. London: Institute of personne Management. 